\title{
Topographic and lithologic controls behind mountain depopulation in Zlatibor District (Western Serbia)
}

\author{
TELBISZ Tamás ${ }^{*}$ (iD https://orcid.org/oooo-0oo3-4471-2889; ${ }^{\circledR}$ e-mail: telbisztom@caesar.elte.hu \\ BRANKOV Jovana2,3 iD https://orcid.org/oooo-0oo3-4032-9030; e-mail: j.brankov@gi.sanu.ac.rs \\ ĆALIĆ Jelena² ${ }^{\text {iD }}$ https://orcid.org/oooo-0002-7271-5561; e-mail: j.calic@gi.sanu.ac.rs \\ ${ }^{*}$ Corresponding author \\ 1 Department of Physical Geography, Eötvös Loránd University, Budapest, Hungary \\ 2 Geographical Institute "Jovan Cvijic”" of the Serbian Academy of Sciences and Arts, Belgrade, Serbia \\ 3 South Ural State University, Institute of Sports, Tourism and Service, 6o, Sony Krivoy street, Chelyabinsk, 454080, \\ Russia
}

Citation: Telbisz T, Brankov J, Ćalić J (2020) Topographic and lithologic controls behind mountain depopulation in Zlatibor District (Western Serbia). Journal of Mountain Science 17(2). https://doi.org/10.1007/s11629-019-5861-5

(CThe Author(s) 2020

\begin{abstract}
Mountain depopulation is a worldwide phenomenon observed in all continents. It has varied socio-economic reasons; among others, the low profitability of traditional agriculture, the better job possibilities and the higher level of services in urban settlements. However, it is often recognized that depopulation is related to natural factors such as elevation, slope or lithology. It is also observed that protected areas are frequently established in depopulated mountain regions. Their primary aim is the conservation of nature, but they may help tourism development as well. Tourism, in turn, may slow down or even reverse the process of depopulation. In this study, we investigate the impact of topographic and lithologic factors, namely of karst settings, on mountain demographic processes and the relationship of protected areas and tourism through the example of the northern part of Zlatibor District (Western Serbia). The study area is characterized by mountains and hills at elevations from 200 to $1600 \mathrm{~m}$ a.s.l. Our aim is to find GIS-based statistical relationships between topographic, lithologic factors and demographic characteristics. In this area, mountain depopulation started after WWII, and we
\end{abstract}

Received: 18-Oct-2019

Revised: 10-Jan-2020

Accepted: 14-Jan-2020 proved that this process was strongly controlled by topographic factors. The higher and more dissected the area, the more significant is the decrease of the population and the more advanced is the ageing. As a result, population density contrasts are much more pronounced now than 70 years ago. After WWII, depopulation and ageing became gradually more serious on karstic terrains than on non-karst. However, by using compound topographic and lithologic types, we proved that it is not the effect of karst, but the effect of topography. The flow of population from hills and mountains to valleys and basins are closely related to the restructuring of the economic sectors. At present, for the study area, the development of tourism is unequivocally naturebased and connected to protected areas, namely to Tara National Park, Zlatibor Nature Park and Šargan-Mokra Gora Nature Park. In this paper, we also demonstrate how lithology influences tourism possibilities. The leading role of Zlatibor in tourism development is largely thanks to its favourable position on a main transit route.

Keywords: Depopulation; Ageing; National park; Tara Mountain; Tourism; Rural; Population density 


\section{Introduction}

Mountain depopulation is a worldwide phenomenon. High mountains were generally relatively rarely inhabited areas during history, but medium mountains, or higher but less dissected terrains provided home to significant populations, where climate conditions were suitable. Obviously, too arid or too cold conditions may cause significant limitations. Some centuries ago, several mountains experienced a growth of population that was due to a general demographic increase as the need for new land drove people to settle in mountainous areas, as the land was the base of subsistence agriculture. The increase of population had varied timing in different mountains from the Middle Ages to the 19th or 2oth century (e.g. Pawson and Egli 2001; Head-König 2011; Telbisz et al. 2016). However, population increase reached an end, and depopulation began. In certain mountains, this process started already in the 19th century, and it became the rule in the 2oth century. Depopulation was described from the Alps (Bätzing et al. 1996), the Mediterranean mountains (McNeill 2003; Collantes and Pinilla 2004; Pejnović and Husanović-Pejnović 2008; Vogiatzakis 2012), several middle mountains in Europe (André 1998; MacDonald et al. 2000; Latocha 2012; Latocha et al. 2016, 2018; Telbisz et al. 2016), the Caucasus (Kohler et al. 2017), the Himalaya (Bhawana et al. 2017), Japan (Okahashi 1996), China (Li et al. 2013; Wang et al. 2019) and Latin America (Grau and Aide 2007). The timing of depopulation, the beginning time and the rate of this process are varied. In several European mountains (e.g. Alps, Apennines, Massif Central, Iberian Mountains), depopulation began in the 19th century (Toniolo 1937; André 1998; Collantes and Pinilla 2004; Viazzo and Zanini 2014), in some other cases (e.g. Velebit Mt, Apuseni Mts), the demographic peak occurred in the first half of the 20th century (Pejnović and Husanović-Pejnović 2008; Telbisz et al. 2016), whereas in many other mountains, depopulation started after the 2nd world war (Romano 1995; Latocha 2012; Wang et al. 2019).

The direct causes of depopulation are natural decrease (birth rates are lower than death rates) and outmigration. The background causes of mountain depopulation are generally similar in most countries, and this process can be interpreted as a special form of rural-urban migration. Notwithstanding, mountains are generally more seriously affected than lowland rural areas (MacDonald et al. 2000; Grau and Aide 2007; Vaishar et al. 2018). Some causes are directly economic: job possibilities are limited and traditional agriculture, typical of mountainous terrains, has low profitability (MacDonald et al. 2000; Grau and Aide 2007; Li et al. 2013). Other causes are related to changes in the way of life. While the level of services (especially education, health, entertainment possibilities) has rapidly grown in urban settlements, the smaller mountain villages were unable to keep up with these developments (Okahashi 1996; Wang et al. 2019). It is documented in a number of cases that parents living in mountain villages intentionally send their children to schools in lowland cities, because this is the way to reach better job possibilities (Okahashi 1996; Wang et al. 2019). Mountainous rural settlements generally have worse conditions than similar size settlements in lowland areas, because transport is more difficult and requires more time in the mountains, thus their isolation is pronounced (Milošević et al. 2010, 2011; Wang et al. 2019). In the process of depopulation, one important factor is how (quickly) the nearby urban settlements can be reached from the mountains (Vaishar et al. 2018).

Nowadays, the formal policy generally supports the maintenance and/or preservation of mountain settlements. In most countries affected by mountain depopulation, there are rural development projects aiming at stopping or at least slowing down the process of depopulation (André 1998; MacDonald et al. 2000; Latocha et al. 2012). Another question is the impact of mountain depopulation on ecological conditions and land use. Although depopulation and its background causes are similar in most cases, the evaluation of its ecological consequences is varied. Some authors (Grau and Aide 2007) argue that the abandonment of mountain areas makes it possible that the landscape approaches a more natural state. Spontaneous reforestation is a typical phenomenon in these areas if climate and other conditions are suitable (Grau and Aide 2007; Sitzia et al. 2010; Bhawana et al. 2017). The spreading of forests usually decreases soil erosion (Latocha et al. 2016). It has a positive impact on greenhouse gases, and 
in general, it may reduce a number of environmental problems (Grau and Aide 2007). On the contrary, other researchers emphasise that secondary forests are ecologically less valuable than the primary vegetation. There are also mountains where cultural landscape is a result of centuries of subsistence agriculture. As a consequence of depopulation and reforestation, certain ecological parameters such as biodiversity or mosaicity of land cover types are reduced (André 1998; MacDonald et al. 2000; Sitzia et al. 2010). Moreover, a cultural impoverishment may also accompany mountain depopulation (Viazzo and Zanini 2014).

Depopulating mountain territories are often found near or inside protected areas. There are several reasons behind this fact. In many cases, the sublime landscape, the biological values or the geoheritage raise the idea of protection. A century ago, the predominant conception was that nature protection is above the interests of local people, thus, people were sometimes relocated from newly generated national parks, which led to a forced depopulation of these mountain areas (Frost and Hall 2015). On the other hand, the exact opposite can also be observed at some territories, which were once relatively densely inhabited. After these territories had become depopulated, they were reforested by natural succession, people started to consider them as natural landscapes, and finally national parks were created on some of these territories (for instance, the Sudetes Mts in Poland; Latocha 2013). In addition, national parks (or recently geoparks) are increasingly considered as tools to stimulate nature-based tourism, which in turn can contribute to sustain local communities or at least slow down the process of depopulation (Romano 1995; Mose 2007; Farsani et al. 2011; Henriques and Brilha 2017; Kohler et al. 2017).

More recently, the trend of depopulation was halted in certain mountains, and in some cases, even repopulation was experienced. The main cause of this change is tourism, especially ski tourism, mountain hiking and recreation in general (Romano 1995; Latocha 2012; Viazzo and Zanini 2014; Gretter et al. 2017). The recent development of transport possibilities, as well as the spreading of tele-working thanks to the internet are also important factors in the repopulation process, but the remote and isolated settlements are still depopulating (Löffler et al. 2014).

In the background of mountain depopulation, natural factors can also be recognized beside socioeconomic causes. For instance, settlements at higher altitudes are increasingly deserted (Kohler et al. 2017). Nevertheless, natural factors (such as relief or climate) cannot be interpreted as determining causes, because socio-economic development can change the strength and even the direction of nature-population relationships (Telbisz et al. 2016). Thus, in lieu of the rigid views of geographic determinism, we use environmental possibilism as a theoretical background. The early ideas of possibilism go back to the famous French geographer, Paul Vidal de la Blache (Mercier 2009). The theory of possibilism states that the environment sets certain constraints or limitations, but culture is otherwise determined by social conditions. The study of statistical relationships between topographic factors and the spatial distribution of population is called „hypsographic demography" by some authors (Small and Cohen 2004; Patterson and Doyle 2011), and we also applied this approach in our previous studies (Telbisz et al. 2014, 2015, 2016, 2019). Several researchers demonstrated that in many cases, there exist statistically significant correlations between depopulation and topographic factors like elevation or slope (Kohler et al. 2017; Latocha et al. 2018).

Our present investigation is performed in the framework of a research project, in which we study the impact of topographic and lithologic factors, namely of karst settings, on mountain demographic processes. Carbonate rocks have a number of specific features, that make karst terrains different from landscapes formed on other rocks. The upland parts of karst terrains lack surface waters, but high-discharge (and vulnerable) springs are typically found at the foot of karst plateaus. In addition, the soils are generally poor on karst areas (Parise et al. 2009; Coxon 2011; Gutiérrez et al. 2014). Further on, the steep, rocky margins of karst plateaus, as well as the narrow gorges are unfavourable for creating transport paths. On the contrary, the spectacular elements of karst morphology (caves, gorges, travertine waterfalls and lakes) are regarded as special opportunities for tourism and nature protection (Zhang et al. 2003; Duval 2006; Mao et al. 2014). As a result of the above-mentioned disadvantages, karst terrains are 
generally more deeply affected by depopulation (Gams 1993; Pejnović and Husanović-Pejnović 2008; Telbisz et al. 2014, 2015, 2016; Vaishar et al. 2018), but due to their advantages, they are often protected areas, and numerous national parks are situated on karst territories (Mari and Telbisz 2018).

Taking into consideration the above factors, we selected a study area from Western Serbia to demonstrate some aspects of mountain depopulation. The study area encompassing Tara and Zlatibor Mountains with their wider environment is a good case study to examine the above processes and relationships, because it is varied in terms of topography. About one fourth of the study area is karstic and contains one national park and two nature parks within its territory. Our aim is to explore relationships between depopulation and topographic-lithologic factors using GIS and statistical analyses. Population density changes, ageing and economic restructuring are also examined. Further on, the role of tourism and nature protection in demographic processes is also highlighted. We have two important hypotheses that we intend to analyse by different statistical parameters. The first hypothesis is that depopulation is more intensive as one gets from lower, less dissected terrains to higher, more dissected terrains. The second hypothesis is that depopulation is more intensive on karst terrains than on non-karstic (or partly karstic) terrains.

\section{Study Area}

The study area is situated in Western Serbia and it encompasses the northern part of Zlatibor District. Altogether, there are 192 settlements within 6 municipalities (Arilje, Bajina Bašta, Čajetina, Kosjerić, Požega, Užice). According to 2011 Census data, 179,329 people live there on $3119 \mathrm{~km}^{2}$, thus the mean population density is 57.5 people per $\mathrm{km}^{2}$. The topography is characterized by mountains and hills at elevations from $200 \mathrm{~m}$ to $1600 \mathrm{~m}$ a.s.l. On average, the elevation gets higher from NE towards SW (Figure 1). The study area belongs to the inner belt of the Dinaric Alps (Geološki Institut Srbije 2009; Ristić Vakanjac et al. 2015). It has a diverse geology with roughly NW-SE oriented structures. In the north-central section, mainly Palaeozoic phyllites and other metamorphites are found. The south-central zone is dominated by Triassic limestones, whereas the southwesternmost and the northeasternmost parts are mainly built up of Jurassic ophiolites (Figure 2).

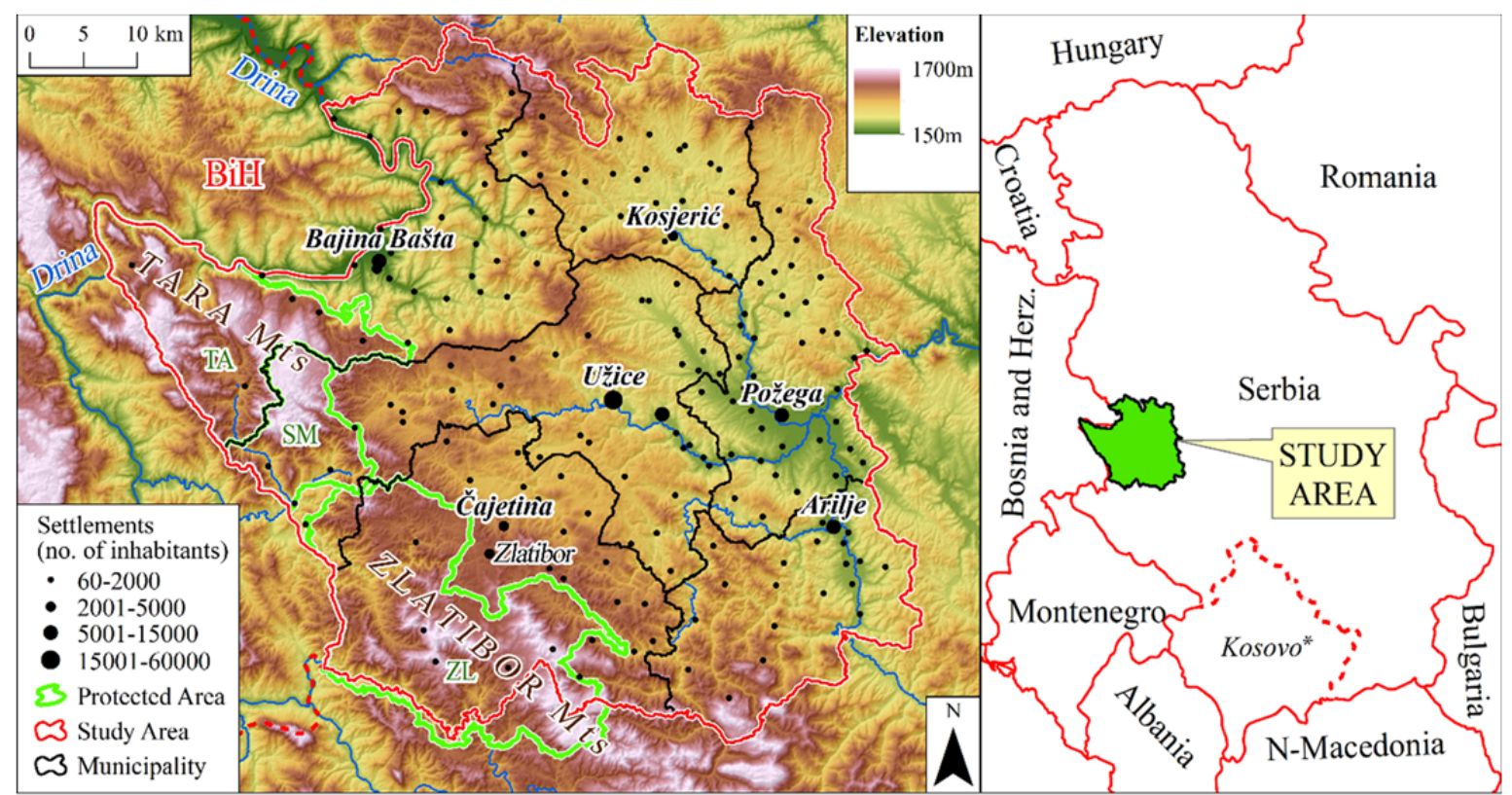

Figure 1 Elevation map of the study area (northern part of the Zlatibor District) with the boundary of the protected areas (TA: Tara National Park, SM: Šargan-Mokra Gora Nature Park, ZL: Zlatibor Nature Park) and of the municipalities, right: overview map showing the location of the study area within Serbia. BiH: Bosnia and Herzegovina (*UN Resolution 1244). 
Further on, the above-mentioned rocks are in some areas covered by younger (Jurassic, Cretaceous and Miocene) clastic sedimentary rocks. Karst features are typical in the south-central limestone zone.

Užice is by far the most important settlement of the study area (Figure 3). It has a central position within the territory, and it is the administrative centre of Zlatibor District. Whichever criterion is considered - either its population or its central functions - it is dominant within the study area, providing home to $29 \%$ of all people living in this territory. Its development was favoured by both natural and social factors. Užice is located just at the margin of the karst terrain, where Djetinja River cut the limestone ridge and created a valley, which is still used as an important transport pathway. The narrow valley of the river is suitable for hydropower production. One of the oldest hydroelectric power plants in Europe according to Tesla's principles was built just here in 1899, and a larger one upstream at Vrutci in 1986. For the defense of the transport pathway, a fortress was built in Užice in the Middle Ages. Most part of the settlement is situated along the river, where the valley becomes wider reaching the non-karstic rocks. As for the recent socio-economic development of the city, it is important to mention that after the Second World War, within the newly established Yugoslavia, a couple of cities across the country were named/renamed after president Tito as a part of his cult of personality. Thus, Užice became "Titovo Užice", which implied that the town received remarkable financial assistance from the state and large investments to infrastructure and local industry, especially in the 1950s. In the following decades, thanks to the rapid industrialization, Užice became a significant town in a Yugoslavian context, and one of the most developed in Serbia. Due to the increased need for workforce, the population started to migrate from surrounding villages to Užice, and new settlements were built at the periphery of Užice. Thereafter, some of them also developed to urbanized settlements, the most impressive example being Sevojno, which today has the status of town. Užice received migrants not only from the rural settlements of its own municipality, but from the whole district.

The study area is a borderland in several meanings. From natural viewpoint, this is a

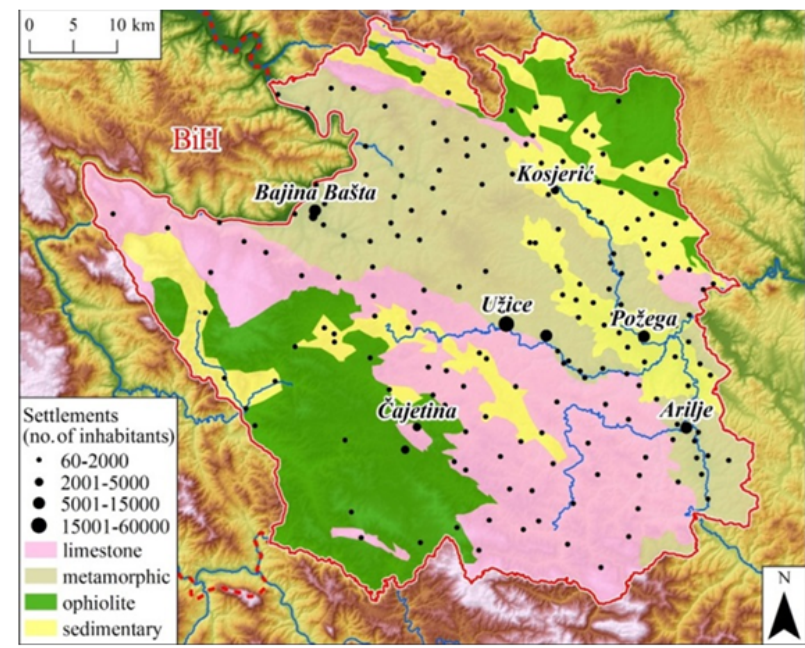

Figure 2 Simplified geological map of the study area. The main rock types are: Triassic limestones, Palaeozoic metamorphites, Jurassic ophiolites, Cretaceous to Miocene clastic sedimentary rocks.

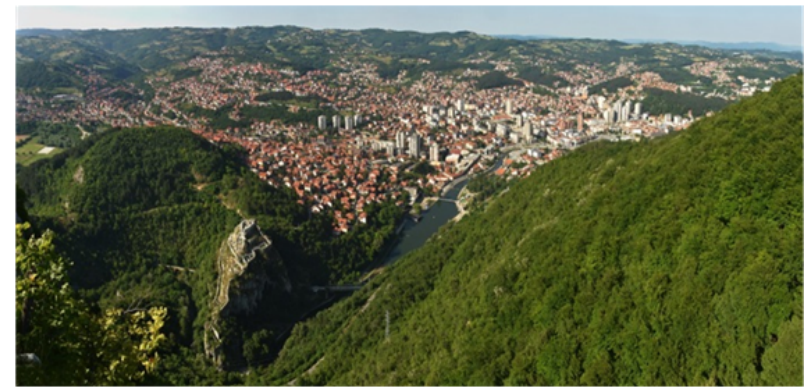

Figure 3 Panorama photo of Užice town with Djetinja River. The town is located just at the lithological boundary. In the foreground, the edge of the limestone plateau can be seen and the ruins of the Medieval fortress are also on a limestone block. In the background, the hilly landscape dissected by fluvial valleys on Palaeozoic metamorphic rocks can be observed.

transitional landscape between the outer high mountains (outer and central Dinarides) and the lower, inner belts of the Dinarides. Historically, this area experienced the Roman Empire, subsequently the Byzantine Empire (being at its western border), the Serbian Medieval state, and for 500 years, the Ottoman Empire. In the late 19th and early 2oth century, the area was within the Kingdom of Serbia and soon after the First World War, it became part of the Kingdom of Yugoslavia. After the Second World War, the study area was a part of the Socialist Federal Republic (SFR) of Yugoslavia, and its western boundary was an inner boundary between the constituent republics. However, the 1990s brought the breakup of the SFR of Yugoslavia, and now the western boundary 
of the study area is an international boundary between Serbia and Bosnia and Herzegovina (Figure 1).

The three protected areas within the study area are: Tara National Park, Šargan-Mokra Gora Nature Park and Zlatibor Nature Park.

In order to clarify toponyms, it is important to mention that the word "Zlatibor" has a triple meaning: first, it is the name of the mountain range and the settlement; second, it roughly overlaps with the area of Zlatibor Nature Park; and third, it is the name of the much wider administrative district (Figure 1).

\section{Data and Method}

In our digital terrain analysis, we used the SRTM dataset (Rabus et al. 2003). The 1 arcsecond resolution (approx. $30 \mathrm{~m}$ ) of this digital terrain model (DTM) is perfectly suitable for this kind of topographic analysis. Settlement centre elevations were derived from this dataset. These values were used for the calculation of the vertical population centroid. In addition, for each settlement administrative area, the mean elevation and relief were also calculated.

Geologic data were derived from the 1:100,000 scale geologic maps (Geološki Institut Srbije 2009). Karst terrains were delineated based on the surface extension of Triassic limestones using some generalization, and in some cases, where the original geological map contained mixed categories, we decided based on our field experiences, whether it belongs to the karst terrains or not.

The source of settlement statistical data (including population, age structure, economic sectors, tourism) is the Statistical Office of the Republic of Serbia. These data were collected during 17 censuses from 1866 to 2011. It is important to mention that for the censuses held between the two world wars (in 1921 and in 1931) data are available only at municipal scale, because even the Statistical Office lacks settlement scale data for these censuses. It is also noted that some settlements were merged or separated after the Second World War, so we took these transformations into account during our settlement-scale analysis. Since 1948, the data series can be considered homogeneous, and they are not affected by the state boundary changes caused by the breakup of Yugoslavia in the 1990s. Migration statistics for the sub-municipal level are not available, so they were not used in our analysis. Tourism data about arrivals and overnight stays were collected separately from the censuses, they are from local statistics, referring to recent years (2015, 2016, 2017).

Data series were analysed at several scales, from settlements through municipalities to the whole area. In this paper, we do not present all data series at all scales, but only the most representative cases.

In order to study the two hypotheses and the other processes mentioned in the Introduction, we categorized settlements in four ways using simple and compound criteria:

1. First, based on lithology, and focussing on karst, we created three categories: a settlement is non-karstic (NK), if the surface proportion of karstic rocks is less than $20 \%$ of the settlement administrative area. A settlement is partly karstic (PK) if karstic rocks occupy 20-50\% of the administrative area, and a settlement is karstic (K), if karstic rocks occupy more than $50 \%$.

2. Second, we classified settlements based on their elevation (a.s.l.). The class interval was $100 \mathrm{~m}$. The lowermost class is 200-300 $\mathrm{m}$, the uppermost class is $1400-1500 \mathrm{~m}$, and one class (1300-1400 m) remained empty. This classification is powerful in terms of statistics, because regression analysis can be applied using class elevation and the selected statistical parameters.

3. Third, based on two DTM-derived parameters (mean elevation and relief), we created complex topographic categories. The first parameter is the mean elevation of the settlement administrative area. The second parameter is relief, i.e. the difference between the maximum and minimum elevations within the settlement administrative area. Relief is a good indicator of surface dissection, and it may strongly influence the land use and transport possibilities of a settlement, therefore it may be in connection with depopulation (Milošević et al. 2010, 2011). Based on these two parameters, six categories have been defined (Figure 4): valley and basin (VB), lower hills (LH), upper hills (UH), partly mountainous (PM), less dissected mountains (LM), and dissected mountains (DM). Category limit values 
were adjusted to the study area settlements, and the values are presented in Table 1.

4. Finally, we created 16 compound litho-topo types by combining the above lithological and topographic categories (Table 2). The compound types are presented in Figure 5 .

The regional centre Užice is treated as a separate type in all cases, because its large size and special characteristics would distort all statistics if it would be put in any category. (Here we note that Užice would be in the partly karstic lithologic category, in the 400-500 m class, and in the lower hills topographic category). Thereafter, we calculated the total and average values of the selected statistical variables for each category / class / type.

\section{Results}

\subsection{Population (density) changes}

Population changes are demonstrated first for each municipality (Figure 6), and based on this image, we can divide the studied period into four phases. From 1866 to the First World War (1910 census), there is a slow, uniform increase in all municipalities. After WWI, a significant population decrease can be observed, and interpreted mainly as a result of human losses in the war, when Serbia lost almost 30\% of its population. Fortunately, this minimum was quickly compensated. Somewhat surprisingly, no similar population reduction can be observed for the 1948 census. The population maximum was reached in 1953 by most of the municipalities (and by most settlements as well). In the 3rd phase, only Užice municipality could dynamically increase its population, while the others stagnated or started to decrease at a slow pace. As a total, the population of the whole study area still grew in that phase, that is thanks to Užice, but the growth rate was already decreasing. The next turning point was 1991, the end of the socialist system in Yugoslavia. This was followed by the breakup of the country, accompanied by wars, but finally, a certain political stability was reached. In this 4th phase, the shrinking of population is accelerated, and even Užice stagnated, then started to decrease.

If settlement scale is viewed, it turns out that

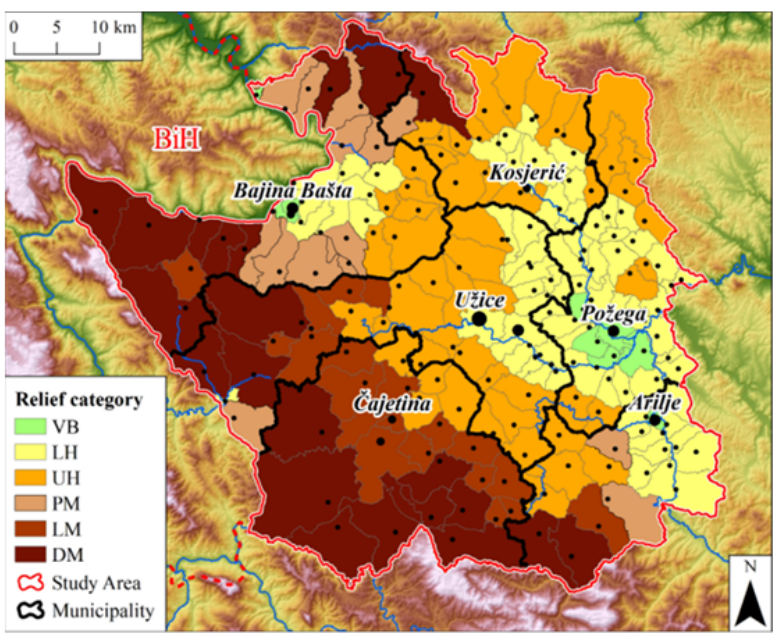

Figure 4 Map of the complex relief categories (using mean elevation and relief values derived from digital terrain models). VB: Valley and Basin, LH: Lower Hills, UH: Upper Hills, PM: Partly Mountainous, LM: Less dissected Mountains, DM: Dissected Mountains.

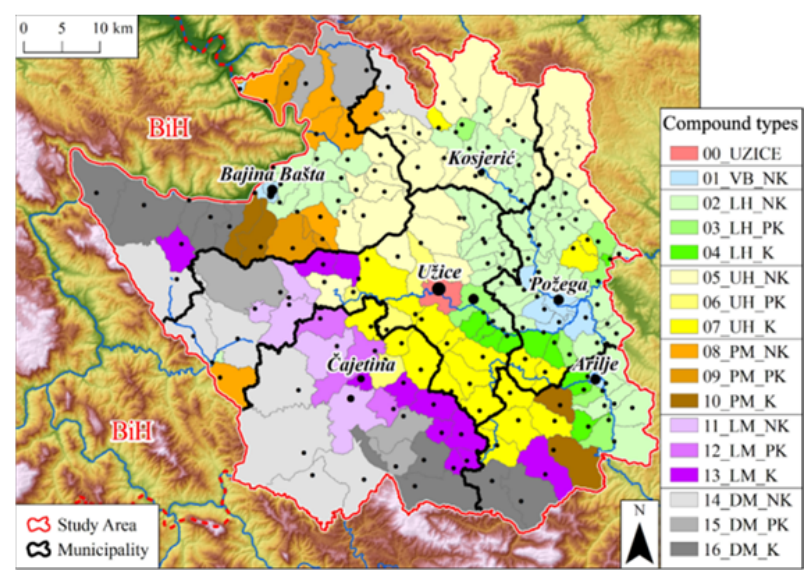

Figure 5 Map of the compound litho-topo types using both topographic (mean elevation, relief) and lithologic parameters. VB: Valley and Basin, LH: Lower Hills, UH: Upper Hills, PM: Partly Mountainous, LM: Less dissected Mountains, DM: Dissected Mountains. NK: non-karstic, PK: partly karstic, K: karstic.

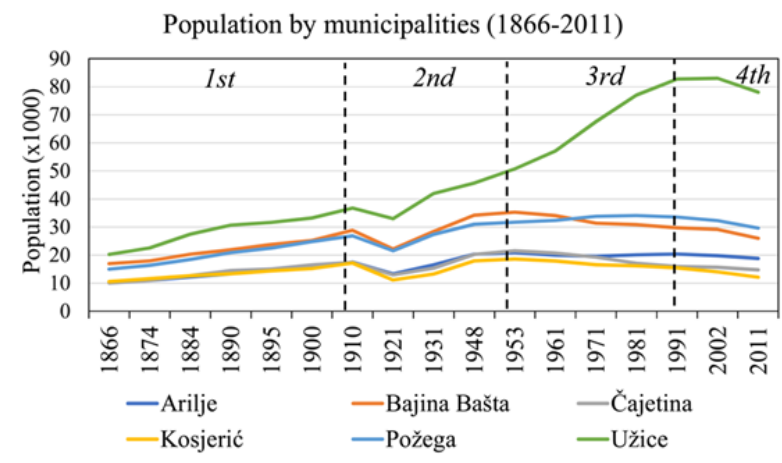

Figure 6 Population changes by municipalities from 1866 to 2011. For explanation of the four phases see the text. 
Table 1 Settlement categories using topographic criteria

\begin{tabular}{|l|l|l|l|}
\hline Category name & Mean elevation (m) & Relief $(\mathrm{m})=$ Max.elev. - min.elev & Number of settlements \\
\hline Valley and Basin (VB) & $200-377$ & $0-230$ & 9 \\
\hline Lower Hills (LH) & $378-600$ & $137-620$ & 75 \\
\hline Upper Hills (UH) & $600-800$ & $137-620$ & 53 \\
\hline Partly Mountainous (PM) & $378-800$ & $620-1040$ & 14 \\
\hline Less dissected Mountains (LM) & $800-1200$ & $260-620$ & 19 \\
\hline Dissected Mountains (DM) & $800-1200$ & $620-1400$ & 22
\end{tabular}

Table 2 Combined settlement types using topographic and lithologic criteria (numbers of settlements are in parenthesis in each type)

\begin{tabular}{|c|c|c|c|}
\hline \multirow{2}{*}{ Relief type } & \multicolumn{3}{|c|}{ KARST type } \\
\hline & Non-karstic (NK) & Partly karstic (PK) & Karstic (K) \\
\hline Valley and Basin (VB) & VB_NK(9) & - & - \\
\hline Lower Hills (LH) & LH_NK (57) & LH_PK (8) & LH_K (10) \\
\hline Upper Hills (UH) & UH_NK (29) & UH_PK (4) & UH_K $(20)$ \\
\hline Partly Mountainous (PM) & PM_NK (7) & PM_PK (3) & PM_K (4) \\
\hline Less dissected Mountains (LM) & LM_NK (5) & LM_PK (3) & LM_K (11) \\
\hline Dissected Mountains (DM) & DM_NK (8) & DM_PK (5) & DM_K(9) \\
\hline
\end{tabular}

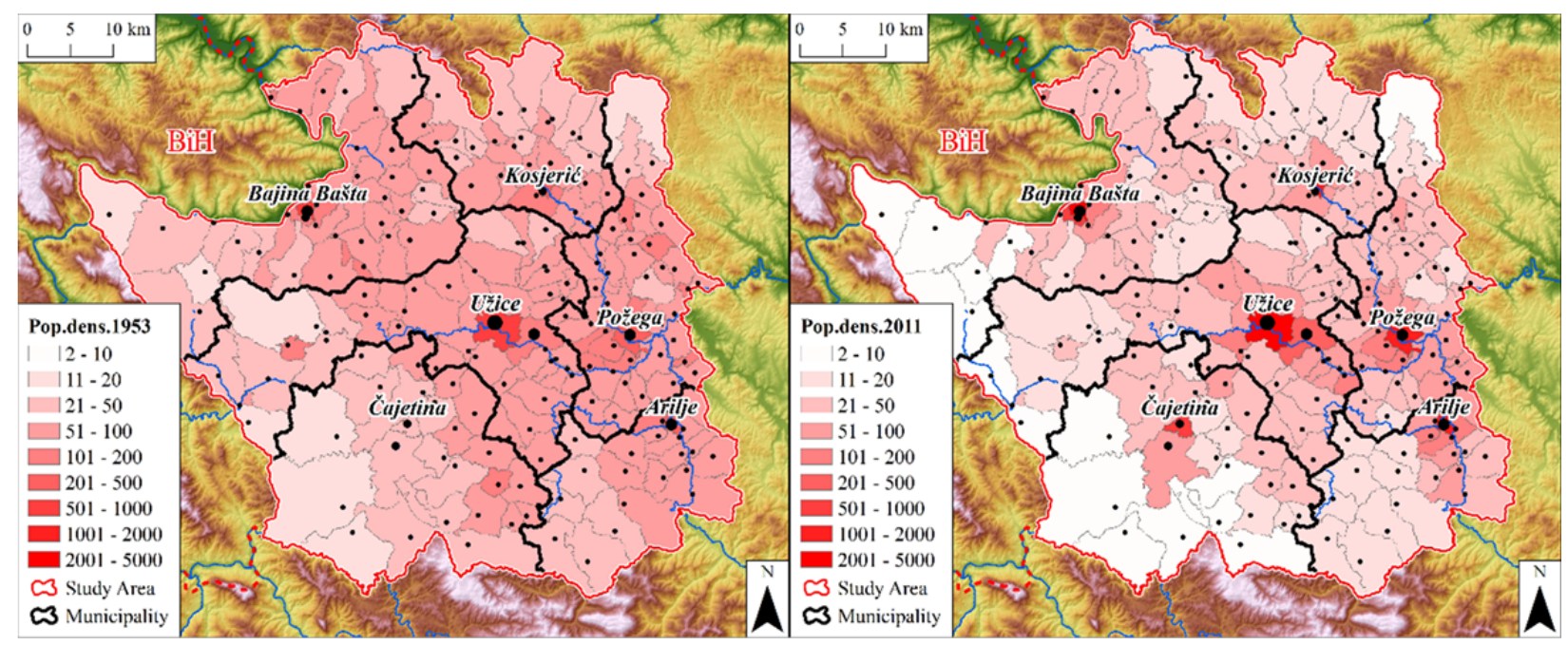

Figure 7 Population density maps (people $\cdot \mathrm{km}^{-2}$ ) of the study area. Left: 1953, right: 2011.

the region was remarkably homogeneous and rural in 1953: there were only 5 settlements where the number of inhabitants was more than 2000. These towns incorporated only $13 \%$ of the total population. Similarly, settlements with less than 500 people were also subordinate with only $8 \%$ of the total population. It means that the overwhelming majority (79\%) of people lived in middle sized (500-2000 inhabitants) villages. To the contrary, in 2011, there were 9 settlements with more than 2000 inhabitants, where $57 \%$ of the total population lived. This fact clearly demonstrates the intensive urbanization during this period. Further on, 18\% lived in settlements with less than 500 people, thus, the proportion of people in tiny villages also increased. During this period (from 1953 to 2011), there were only 17 settlements (of 192), which experienced a positive population balance. The strong influx of population into urbanized areas and the abandonment of rural, mountainous terrains can be well characterized by the comparison of the 1953 and 2011 population density maps (Figure 7). Population growth is limited to few towns and their satellite settlements, with only one exception: the Čajetina-Zlatibor double settlement. This latter case is unambiguously connected to the prosperity of nature-based tourism.

As for the timeline of population density changes, Figure 8a demonstrates that non-karstic, partly karstic and karstic terrains moved together until 1953. However, since that year, the lines are 
differing. The population density of non-karstic areas stagnated, whereas the population density of karstic terrains quickly decreased, and partly karstic areas were in-between these two.

Population density time series by elevation classes (Figure 8b) demonstrate that till 1948, population density increased in each class. Thereafter, only the lowermost classes (200-300 m and $300-400 \mathrm{~m}$ ) could increase their population starting from an a priori higher value. On the contrary, the higher elevation classes were characterized by stagnation and depopulation. The only exception is the $900-1000 \mathrm{~m}$ class, where population was relatively stable. This is again due to the aforementioned Čajetina-Zlatibor, which belong to this class. Statistical regression analysis was applied to the relationship of population density and elevation a.s.l. (Figure 9). In 1953 (and in the previous periods alike), there is a strong linear relationship between population density and elevation, with correlation coefficients $(r)$ higher than 0.9. Since 1953, due to the abovementioned demographic changes and the flow of people towards lower terrains, the correlation type has changed, it has become exponential, but the relationship is still strong (Figure 9b).

The above facts seemingly imply that both topography and lithology have an impact on population density (changes). However, in this study area, the spatial distribution of karstic rocks is not independent from topography as the proportion of karstic terrains is much higher in the mountains than in the lower categories. Consequently, it is necessary to discriminate the effects of these two factors. Figure 10 helps us to understand the relationship of population density and the compound litho-topo types. (Here we note that the trend lines in Figure 10 are only to help visual interpretation, but as types are nominal classes in that case, statistical regression analysis can not be carried out.) Figure 10a presents that in 1953, population density gradually decreases towards higher and more dissected litho-topo types. However, within topographic categories, there are no clear and unequivocal differences between nonkarstic, partly karstic and karstic terrains. By 2011, the population density increased in only two of the types (VB, LH_NK), but all other types suffered population density decrease. Somewhat surprisingly, the largest decrease can be observed

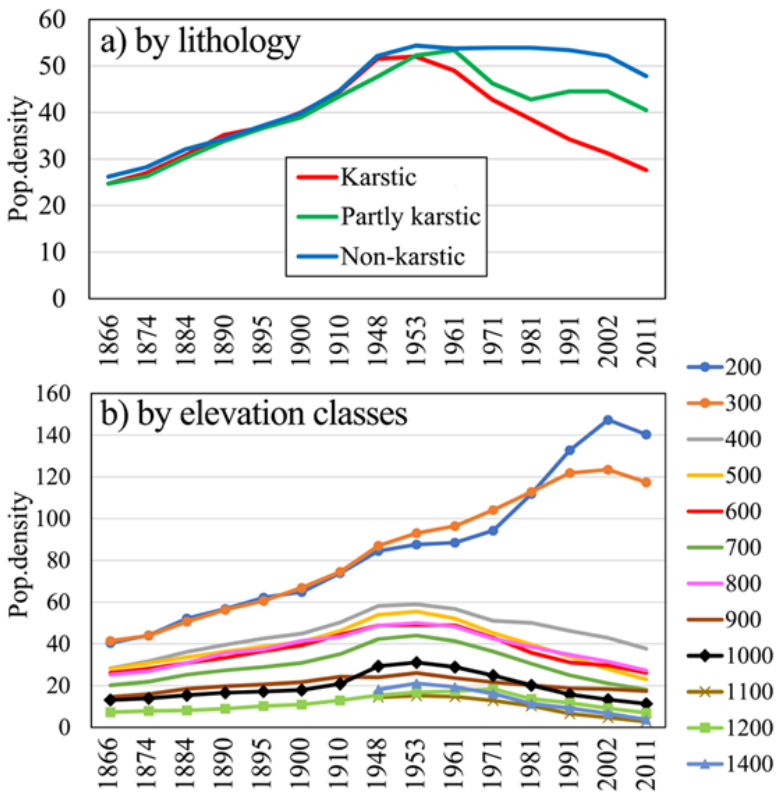

Figure 8 Changes of population density (Unit: people $\cdot \mathrm{km}^{-2}$ ) (a) by lithology, (b) by elevation classes.
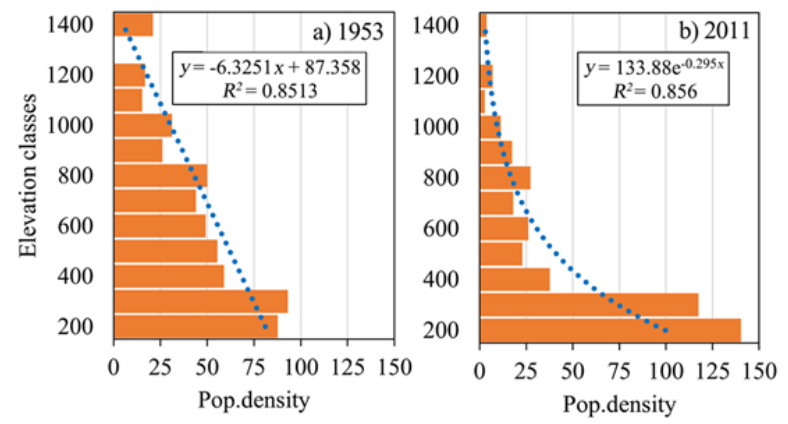

Figure 9 Statistical regression analysis between population density (Unit: people $\cdot \mathrm{km}^{-2}$ ) and elevation (Unit: m), (a) in 1953, (b) in 2011.

in the PM category. In general, we can state that in the upper hills (UH) and the mountainous types, the values approach a quite similar low-density level. As a result, the population density differences between the lower, less dissected and the higher, more dissected topographic categories are much more pronounced in 2011 than in 1953. In order to clearly demonstrate the rearrangement of population within the study area, the vertical population centroid is presented in Figure 11. It shows that the centroid remained almost constant, in the zone 560-575 $\mathrm{m}$ a.s.l. from 1866 to 1953 , and the downward movement took place since 1953 . This trend was the most intensive during the 3 rd phase, until 1991.

It is also interesting to examine the 


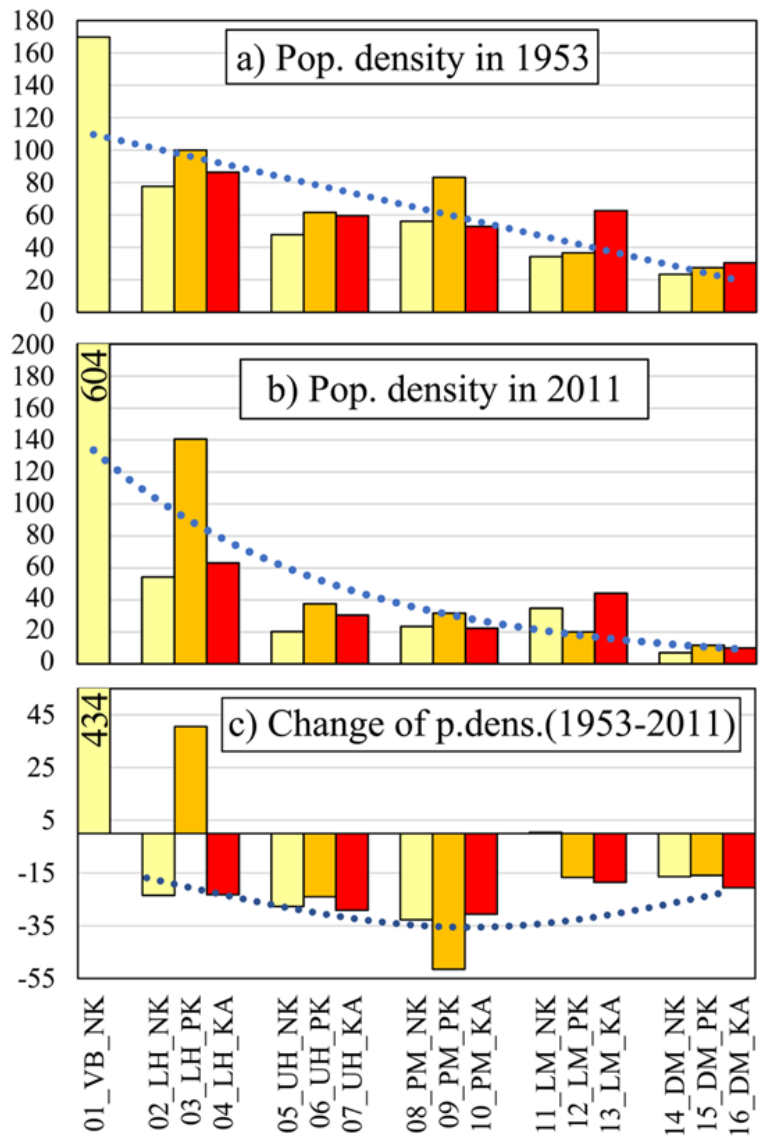

Figure 10 Population density (Unit: people $\cdot \mathrm{km}^{-2}$ ) by compound categories (a) in 1953, (b) in 2011, (c) change from 1953 to 2011.

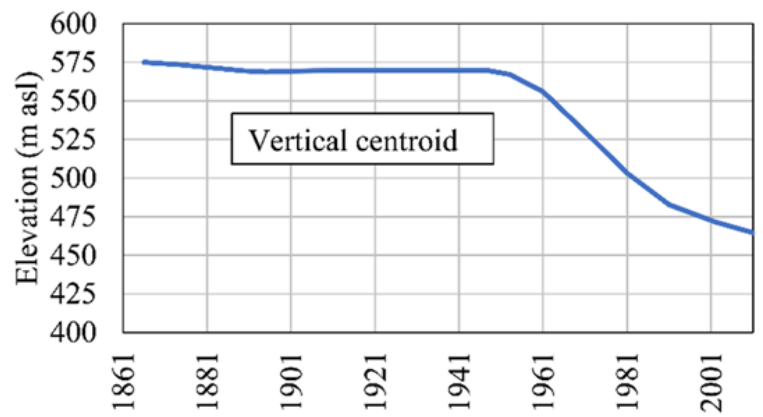

Figure 11 Changes of the vertical population centroid of the study area.

characteristic settlement size in terms of the number of inhabitants, how it changes with topography or lithology. The characteristic size can be best represented by the median population value, because the arithmetic mean is often distorted by outliers. Figure 12 presents that in 1953, settlement median population was more numerous in higher and more dissected types. At that time, the median population was higher than

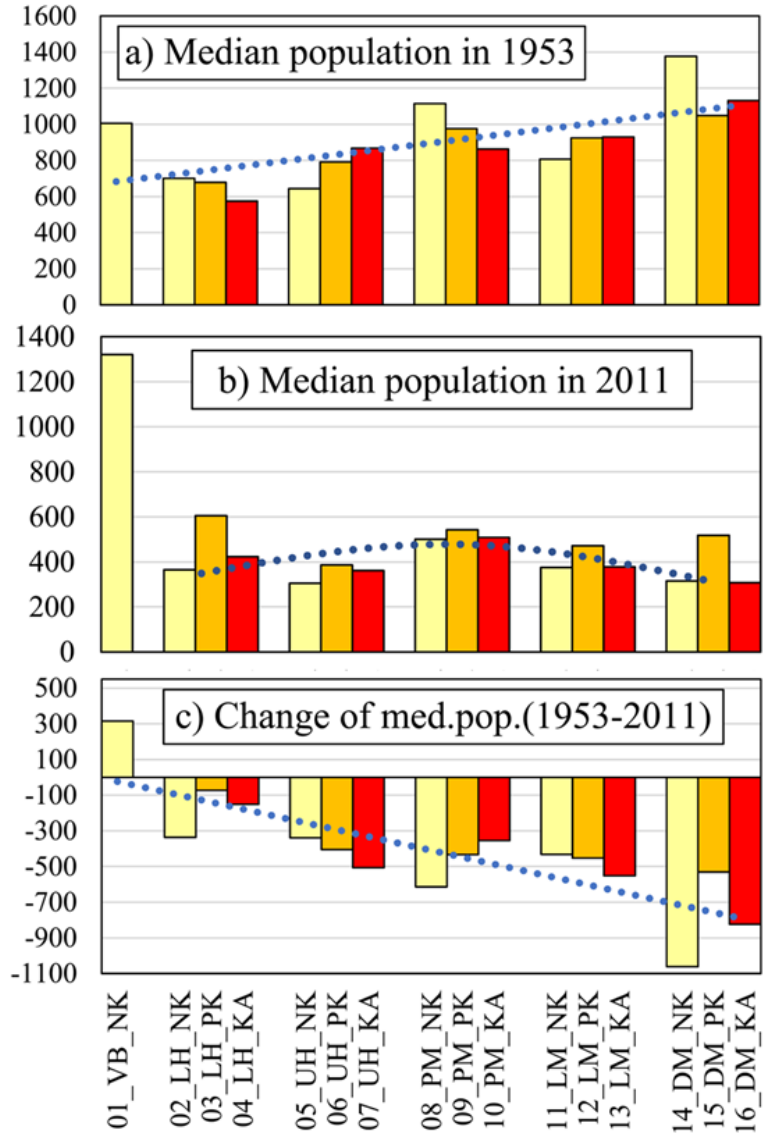

Figure 12 Median settlement population by compound categories (a) in 1953, (b) in 2011, (c) change from 1953 to 2011.

600 in the lower hills (LH), whereas in the mountainous categories the median values were around 1000 people. It means that mountainous settlements typically had more inhabitants than hilly settlements. It is also noted, that many of these mountain settlements have a dispersed pattern, and administrative settlements generally incorporate several smaller parts. By 2011, the trend and the values were clearly changed. While in the valley and basin (VB) type the settlement sizes increased, all other types experienced a reduction in the median settlement size, and in most cases the median population is now around or below 400 people. This figure again highlights that karst has no effect on this parameter. Thus, we conclude that within this western Serbian study area, the spatial pattern and the temporal changes of population are unequivocally influenced by the impact of topography, while the apparent lithologic (karstic) effect is only due to the fact that karstic terrains are generally in the higher topographic categories. 


\subsection{Ageing}

Ageing is characterized here by the proportion of people older than 60 years (Figure 13). In 1948, this proportion was $6 \%-7 \%$ in all types. This indicates that the study area was remarkably homogeneous, and this parameter was basically independent from topographic and lithologic factors. In the period which followed, the proportion of old people began growing. On the higher and more dissected lands, this growth started in 1948, while in the valleys and lower hills, ageing started to increase only after 1981. As a result, by 2011, the mean value of this proportion reached $31 \%$ in karstic settlements, whereas the average of partly karstic and of non-karstic settlements was uniformly $26 \%$. Nonetheless, if the compound litho-topo types are examined, we have the same conclusion as in case of population density, i.e. there are no significant differences between karstic, non-karstic and partly karstic terrains within topographic categories, and even it is observed that non-karstic or partly karstic settlements have slightly higher proportion of old people than karstic settlements, if the topographic conditions are the same. Therefore, we state that the lithologic factor does not have an impact on ageing. On the other hand, the topographic control is obvious in 2011 as in the valleys and lower hills, the proportion of old people is $20 \%-27 \%$, while in the dissected mountains, this proportion grows up to $37 \%-45 \%$. In addition, there is a strong linear correlation $(r=0.90)$ between the proportion of old people and elevation, if the $100 \mathrm{~m}$ interval elevation classes are considered and one extreme value (Stublo settlement with $65 \%$ people older than 60) is removed from the analysis. On the contrary, in 1948, before depopulation and ageing became intensive processes, there was no correlation between the proportion of old people and elevation $(r=0.14)$. Thus, we conclude that in the study area, ageing and depopulation resulted in a topographically controlled ageing distribution by 2011, compared with the original (1948) relatively uniform ageing distribution. This conclusion is supported by Figure 14 as well, which illustrates that mountainous areas have higher proportion of old people, whereas towns along river valleys have low values. The exception is again Čajetina and the neighbouring settlements, where the proportion of old people is relatively low.

\subsection{Structural transformations}

Transformations between the three main economic sectors were remarkable during the post WW2 period (Figure 15). The oldest available data about the economic sectors of settlements are available from 1953 on. At that time, the whole area was predominantly an agrarian landscape, where about $90 \%$ of the population worked in the primary sector, which in this case means almost exclusively agriculture. The only category, in which agriculture was not dominant at that time was the "valley and basins", where the primary sector was $42 \%$ and the tertiary was $45 \%$ at the start of the period. The 1953-2011 period is characterized by a strong reduction in the agrarian sector. This started earlier in the lower terrains (VB, LH), and later in the higher categories (UH, PM, DM). In the latter categories, $50 \%-60 \%$ of people still work in the agricultural sector in 2011. The exception among the higher categories is the LM category (less dissected mountains including Čajetina settlement), where agriculture was decreased to as low as $20 \%$ by 2011.

In the 1960 s and 1970s, most part of the population moved to the secondary, industrial sector, while the tertiary sector became more important since the 1980s. A further phenomenon is that unemployment became gradually higher from the 1970 s to 2002. Namely, it started to grow already during the socialist time, but reached its peak in all categories by the end of the "turmoil" associated with the disintegration of Yugoslavia. In

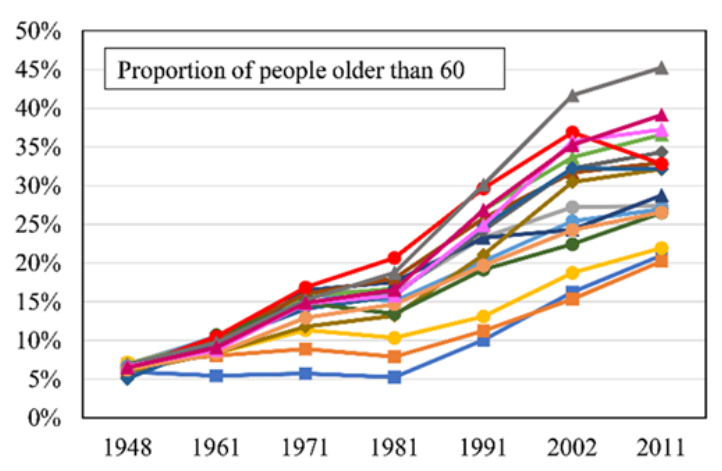

Figure 13 Changes of the proportion of old $(60+)$ people by

compound categories.

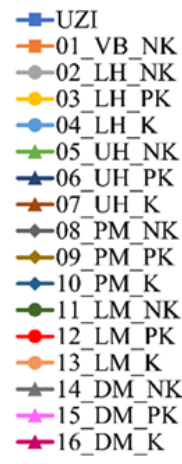



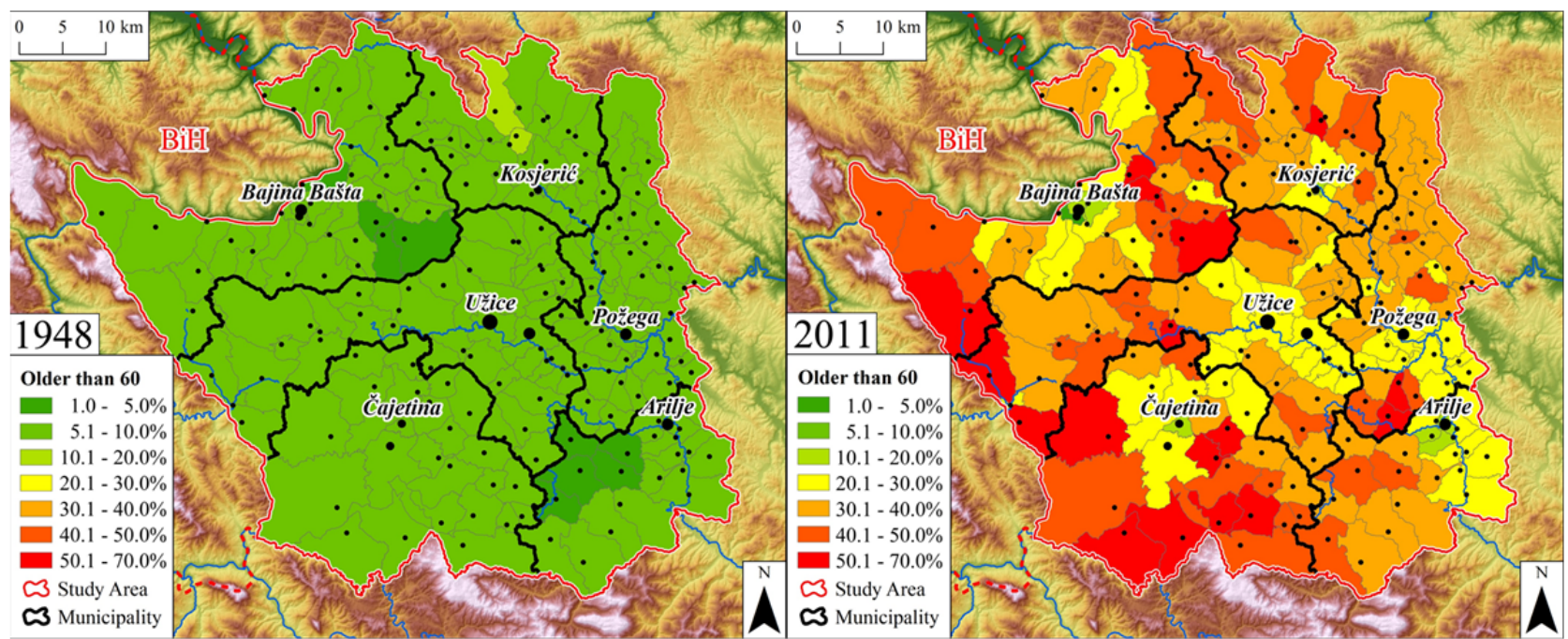

Figure 14 Map of the proportion of old (6o+) people in 1948 (left) and in 2011 (right).

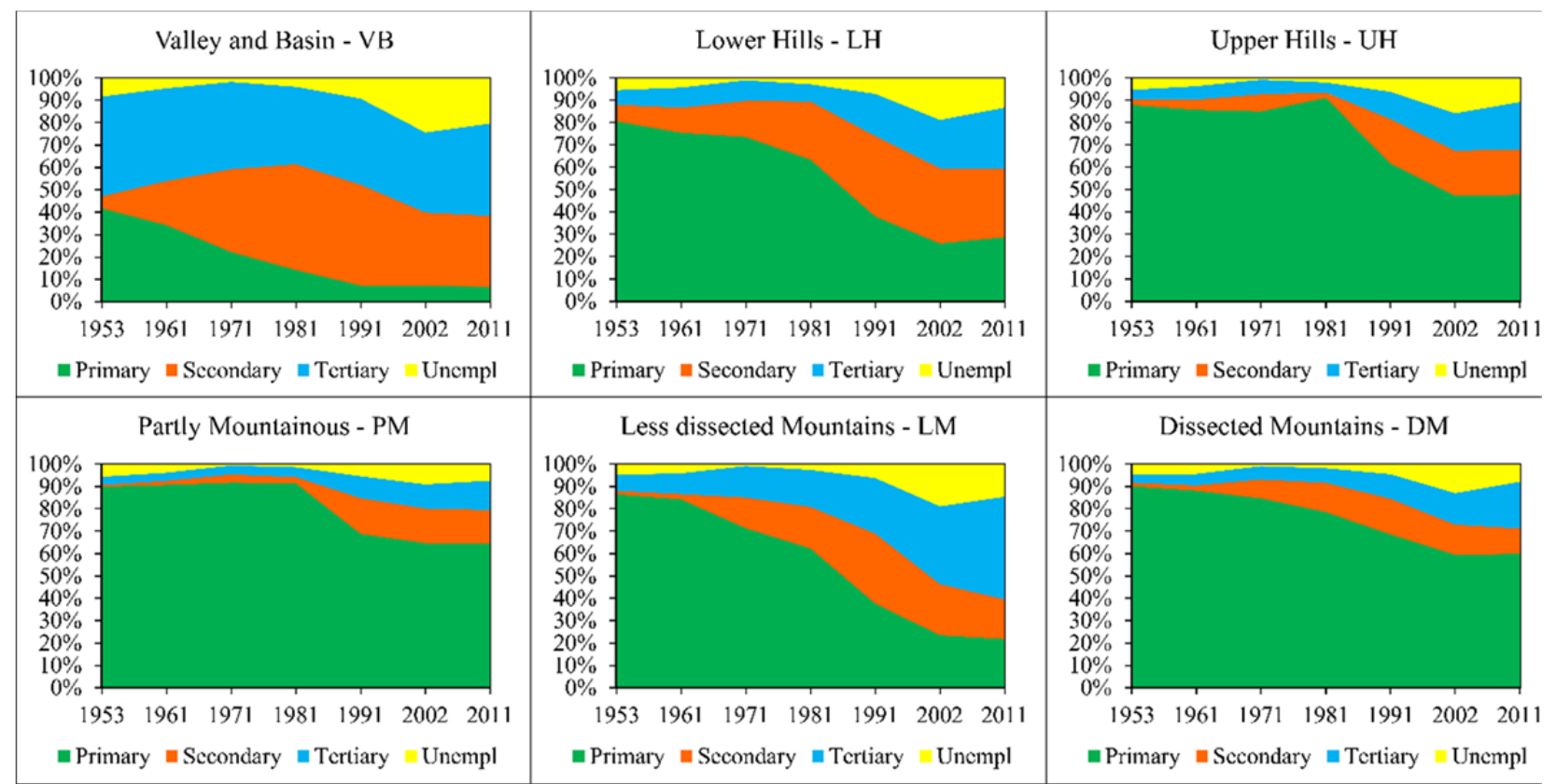

Figure 15 Economic restructuring from 1953 to 2011, by topographic categories.

the first decade of the 21st century, tertiary sector grew in all categories, especially in the less dissected mountains, where its proportion is the second highest (46\%) after Užice town (50\%), due to tourism (see the next section). As for the compound litho-topo types, Figure 16 proves that within topographic categories, there are no unequivocal differences between karstic, nonkarstic and partly karstic terrains. This again underlies that within the study area, the topographic control is important, but the lithological control is not significant in the restructuring of the economic sectors.

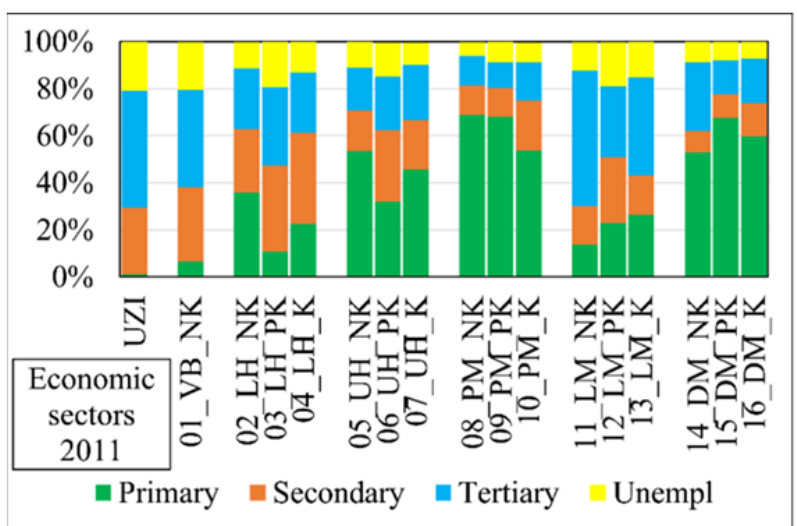

Figure 16 Economic sectors by litho-topo types in 2011. 


\subsection{Tourism and protected areas}

Tourism sector was firstly introduced into the census as a separate category in 1981, thus we start our analysis from that date. The major part of the study area (including towns) are not really significant tourist targets, as it is reflected by the fact that in 1981, the proportion of people living from tourism was only $1 \%-3 \%$ in all topographic categories except one - the less dissected mountains (LM), where it was slightly higher (5\%). In most part of the study area, tourism could increase only by 1 percentage point till 2011, but it grew more significantly, up to $13 \%$ in the category of less dissected mountains. Like in case of the previous parameters, we do not see any impact of lithology on tourism within the topographic categories. However, there is an exception, the less dissected mountains, where the tourism sector has $19 \%$ on non-karstic, $12 \%$ on partly karstic and only $10 \%$ on karstic terrains, which is just the opposite of our previous hypothesis.

The map of the proportion of the tourism sector (Figure 17) as well as the numbers of guest arrivals and overnight stays (Figure 18) demonstrates that the main tourist targets are found in the mountain ranges at the southwestern part of the study area, in the mostly ophiolitic Zlatibor Mt and in the karstic Tara Mt. These facts demonstrate that nature-based tourism and connected rural tourism are the dominant forms of tourism within the study area. Moreover, it is noted that tourism is largely domestic. Before 1990, Yugoslavia had diverse and majestic tourist targets in several former constituent republics (e.g. in Croatia, Montenegro, Bosnia and Herzegovina, Slovenia), thus tourism was less important in the study area during the 1970 s and 1980s. The political crisis and the wars of the 1990 s had a deep impact on tourism as well. However, in the consolidation period, this territory became more valuable within Serbia as a tourist target and tourism was gradually developed. Later on, international visitors also appeared, although their number is still well below domestic visitors.

Tourist targets are connected to three protected areas (Tara National Park, ŠarganMokra Gora Nature Park, Zlatibor Nature Park). The proportion of tourism sector is the highest not in the geometric centroids of these protected areas, but along the boundaries, rather outside the protected area. In case of Tara National Park, there is Bajina Bašta as the administrative centre of the national park, and this town is outside the park area. In case of Zlatibor Nature Park, Čajetina and Zlatibor settlements are the most important targets. These two even constituted a single settlement before 1948 .

Among the protected areas, Tara National Park is the oldest, as it was established in 1981. The primary goal of this foundation was to protect biological values, especially the local forests, which have high biodiversity and preserve many endemic species like the Serbian spruce Picea omorika Pančić, but the population of brown bear is also very significant here. In addition, the geomorphological values, namely the gorges, especially the large valley of the Drina River (Figures 19, 20), as well as exokarst landforms and springs were also important factors, which contributed to the declaration of this national park. Therefore, nature protection goals are of primary

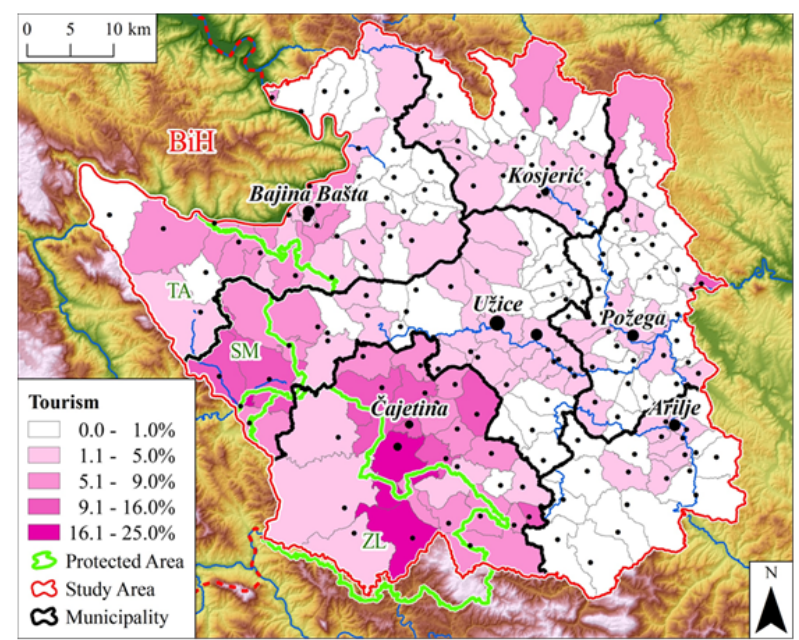

Figure 17 Map of the proportion of people working in tourism industry.

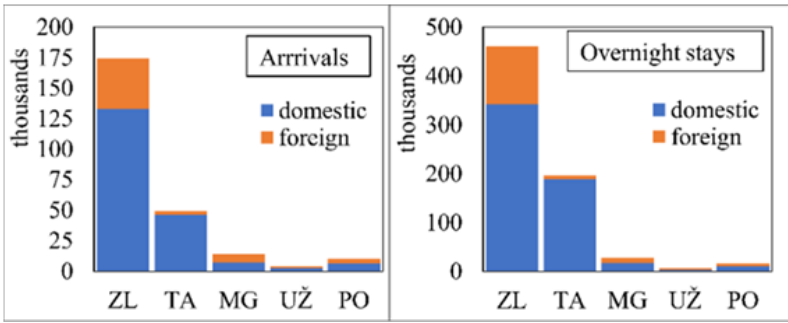

Figure 18 Tourist arrivals and overnight stays in the touristic destinations of the study area (yearly average values for 2015-2017). ZL: Zlatibor area, Ta: Tara area, MG: Mokra Gora area, UŽ: Užice area; PO: Požega area. 


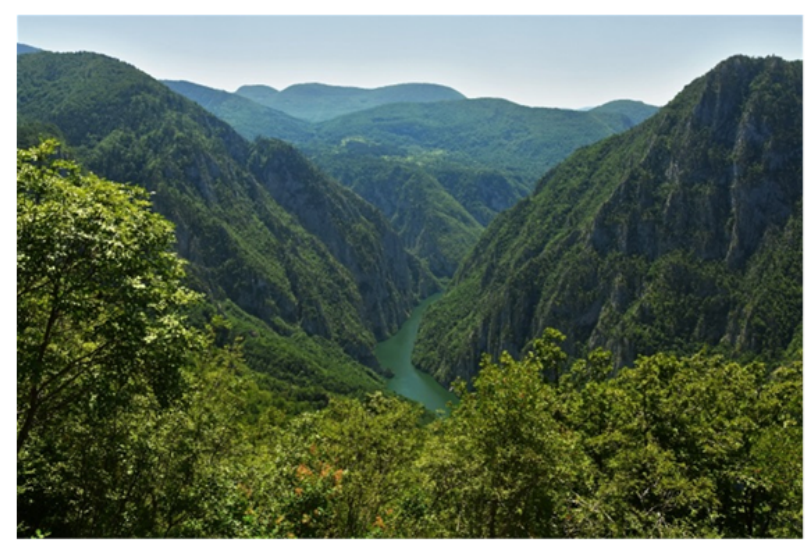

Figure 19 Drina River gorge at the state boundary; Serbia is to the left, Bosnia and Herzegovina is to the right.

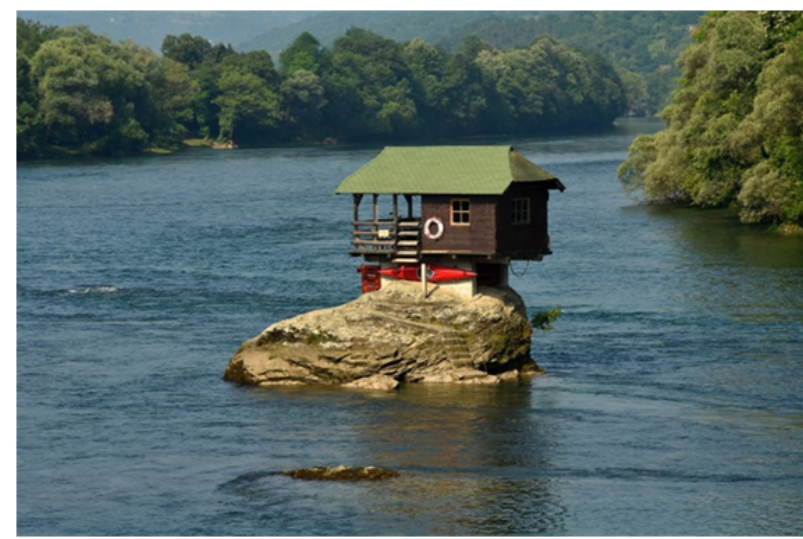

Figure 20 Iconic image of the Drina River with a small hut on the rock.

importance and tourism is only secondary. However, several hotels and a children/youth camp well-known in all Serbia are also found in the middle of the Tara National Park. On the other hand, Šargan-Mokra Gora and Zlatibor Nature Parks were established only recently, the former in 2005, the latter in 2017. In these cases, beside the bio- and geoheritage, the purpose of intensifying the already existing tourism also played a significant role. It is noted that the tourism of Zlatibor is more than a century old. The then king of Serbia Aleksandar Obrenović visited this location in 1893, and he initiated the creation of a new health resort in the area.

The nature of tourism on Zlatibor and Tara is different in several points, partly due to their differing geological settings. As Tara Mt is built of mostly karstifiable rocks, they are more vulnerable, the availability of water is limited on the karst uplands, and the topographic characteristics (i.e. the steep edges and the flat plateaus) determine that only cross-country skiing has a potential among winter sports. So, Tara is rather for intact nature lovers. On the contrary, Zlatibor is nonkarstic, thus it is less vulnerable, rich in water, and the fluvially formed hillslopes are suitable for skiing. Furthermore, crucial to the development of tourism in Zlatibor was its position on the transit traffic route that enabled large and continuous tourist flow and diversified demand. These are the reasons why the development of mass tourism affected mainly Zlatibor. The tourism function was so strong in Zlatibor area that it implied other activities, improved the infrastructure facilities, stimulated year-round tourist arrivals, and finally contributed to the development of settlements and demographic growth (Devedžić 2007). In Zlatibor, even luxurious hotels are present, and it became a prestige tourism destination. Mass tourism has several positive economic effects, but at the same time, it implies a large burden on the environment, so the foundation of the nature park is also important in order to strengthen the conservation of nature. As Figure 17 demonstrates, both the arrivals and the overnight stays are 2-3 times higher on Zlatibor than on Tara.

\section{Discussion}

Demographic changes in the study area must be evaluated in the Serbian context. It is observed that population changes in the study area during the 2nd half of the 2oth century were similar to the trends of the whole country. Namely, after the Second World War, in the 1950s, the population growth rate was high in whole Serbia (about $10 \%$ o/year-12\%o/year), then it had a slowing increase rate (8\%o/year-1\%o/year) until 1991. Increase rates of the study area were similarly high at the beginning of the 1950s, but later on, they were about half of the whole country values (4\%o/year-1\%o/year). The census of 1991 showed a turning point in whole Serbia, because population decreases since that time in the whole country and the studied territory alike.

By comparing the timing of mountain depopulation in the study area to other mountains of Europe, we find that the flow of people from higher terrain to the valleys and lowlands began here later than in the typical mountains of Western and Southern Europe (e.g. the Alps, the Massif 
Central, the Apennines, etc.; Bätzing et al. 1996; André 1998; McNeill 2003; Collantes and Pinilla 2004; Pejnović and Husanović-Pejnović 2008). In the Alps, there are several locations, where depopulation halted and even repopulation is observed (Viazzo and Zanini 2014; Löffler et al. 2014). In our study area, this phenomenon is limited to few settlements of the Čajetina-Zlatibor area. As André (1998) notes, middle mountains are commonly in a more difficult situation than high mountains, because high mountains are generally richer in spectacular tourist attractions. We believe that this statement is valid for the northern part of Zlatibor District as well. Further on, it is observed that repopulation processes occurred later on Zlatibor than in the Alps, because in the latter mountains, certain settlements had a growing population already in the 1980 s (e.g. in the French Alps, Löffler et al. 2014). On the contrary, while completely abandoned settlements are found at several locations in the Mediterranean world, they are not yet present in our study area and the smallest settlement in 2011 had 60 inhabitants.

If we try to predict future situation of the study area, we can say that according to our analysis, recent processes point towards further polarization in both economical and demographic meaning. Thus, four typical scenarios are anticipated: (1) towns (including Užice) located in the valleys and basins will continue to be the targets of internal migration, but their population will decrease in absolute numbers. (2) Settlements in the upper hills and mountainous areas, which lack special attractions (like protected areas) will fall behind other settlements in the competition for tourism, thus their population reduction and ageing will continue, occasionally until the total abandonment of the village. This is the likely future of the highest and most remote settlements. (3) Settlements near the protected areas are the most profitable from a touristic point of view, thus an adequate development can halt or turn depopulation. The local management should be wise enough to preserve the natural basis of tourism and to avoid environmentally harmful developments. Moreover, managers should try to broaden the benefits to several settlements and to support local communities since tourism often focuses on a single settlement (or area) leaving the neighbours underdeveloped (Bätzing et al. 1996; Collantes and
Pinilla 2004). The improvement of infrastructure is also important in increasing the chances. It seems likely that only a part of the potential tourist settlements will be able to get the possibilities and develop, while the others will follow the scenario (4). This last scenario means that in spite of their relatively favourable natural settings, their population will continue to decrease. Type examples for scenario (3) are found in Zlatibor Mt, whereas Tara settlements are more likely to follow scenario (4).

Blagojević (2012) studied small villages in Tara National Park, which are now on the way towards extinction. An optimal strategy to maintain these villages would be the development of rural tourism and the production of local food (e.g. cheese, honey). For the time being, tourism has a weak impact on the local communities of Tara in terms of knowledge and personal involvement (Brankov et al. 2019). Nonetheless, the own resources are not enough for this strategy as most of the villagers are old, lacking modern knowledge about enterprises and marketing (cf. MacDonald et al. 2000). Thus, the national park or other organisations should help these villages by infrastructure development, knowledge transfer, financial support and common marketing to maintain them. Without this help, the extinction of these settlements and natural succession is the most likely scenario.

Recently, it is repeatedly articulated that protected areas should serve the maintenance of local communities, although little information has been published so far about how successful these ideas were in reality (Mose 2007). Within the study area, protected areas are unambiguously important from the viewpoint of tourism. In case of Zlatibor $\mathrm{Mt}$, the recent foundation of the nature park aims at the further development of the already existing tourism, and it is in fact the area, where settlements could maintain or slightly increase their population and where further increase is likely. On the contrary, on Tara Mt, even if the foundation of the national park had occurred much earlier, the process of depopulation would not be halted. In this latter territory, we plan further research to explore the possibilities and attitudes of local people, the relationship of local communities and the national park, as well as the motivations and attitudes of visitors coming to this area. 


\section{Conclusions}

Our GIS-based analysis focusing on the northern part of the Zlatibor district (Western Serbia) as a case study lead to the following conclusions. In terms of demography, the area remained remarkably homogeneous till the end of the WW2. The population density had an upwards decreasing trend according to a linear function. At that time, the proportion of old people was low and uniform throughout the whole study area, irrespectively from elevation. Moreover, the area was an agrarian landscape, where $80 \%-90 \%$ of people lived from agriculture, except in the valleys and basins.

Depopulation began in the second part of the 2oth century, and this process has been strongly controlled by topographic factors. On the settlement level, it means that the higher and more dissected the area, the more significant is the decrease of the population and the more advanced is the ageing. The total population of the study area has been decreasing since 1991, that fits the general trend of Serbia, however, the internal rearrangement and population flow from the mountains towards the valleys and basins started already in the 1950s. The lowering of the vertical centroid was the most intensive in the 1960 s and 1970s, but this process still continues today, though at a lower rate. As a result, population density contrasts between mountains and valleys have become more pronounced by now. Till the 1950s, there had been no population density differences between karstic, partly karstic and nonkarstic terrains, but since that time, depopulation and ageing have been much more significant on karst. However, it is a somewhat misleading relationship, which is valid only because karst terrains are situated predominantly in the mountainous areas. By creating compound topographic and lithologic types, we proved that

\section{Acknowledgements}

This research has been supported by the National Research, Development and Innovation Office Hungary (NKFIH) K124497 project and by there are no unequivocal differences in the demographic parameters between karstic, partly karstic and non-karstic terrains if topographic categories are treated separately. These conclusions mean that our previous results about the impact of karst on population statistics (Telbisz et al. 2014, 2015, 2016) can not be automatically extended to each karst area, thus individual investigations are necessary in each case.

The flow of population from hills and mountains towards the valleys and basins are closely related to the restructuring of the economic sectors. Industrialization in the 1960 s and 1970 s was strongly supported by economic policy, especially in case of Užice, the central town of the region. However, in the upper hilly and mountainous areas, the majority of people still work in the primary sector. The tertiary sector could increase significantly only in the valleys and basins as well as in the less dissected mountains, because this latter type includes the most important tourist targets of the study area. At present, the development of tourism is unequivocally nature-based and connected to protected areas. We also demonstrated that lithology influences tourism possibilities for several reasons. In many karst areas worldwide, the special karst landforms (like caves, gorges and waterfalls) attract loads of tourists. However, in the present case study, we found rather that karst settings imply certain constrains: the water scarcity, the vulnerability of karst and the lack of slopes suitable for skiing eventuated that the tourism of the karst area (Tara National Park) is less developed than the tourism of the nearby ophiolitic mountains (Zlatibor Nature Park). In addition to the above factors, the tourism development of Zlatibor Nature Park was significantly stimulated by its favourable position on one of the main transit routes.

the Ministry of Education, Science and Technological Development of the Republic of Serbia (47007 III project). 


\section{Open Access}

This article is distributed under the terms of the Creative Commons Attribution 4.0 International License (http://creativecommons. org/licenses/by/4.0/), which permits unrestricted use, distribution, and reproduction in any medium,

\section{References}

André M-F (1998) Depopulation, land-use change and landscape transformation in the French Massif Central. Ambio 27:351-353

Bätzing W, Perlik M, Dekleva M (1996) Urbanization and depopulation in the Alps. Mountain Research and Development 335-350. https://doi.org/10.2307/3673985

Bhawana K, Wang T, Gentle P (2017) Internal Migration and Land Use and Land Cover Changes in the Middle Mountains of Nepal. Mountain Research and Development 37: 446-455. https://doi.org/10.1659/MRD-JOURNAL-D-17-00027.1

Blagojević I (2012) Sustainable Landscape Management in Tara National Park (Village Jagoštica, Serbia). Geographica Pannonica 16: 94-102.

https://doi.org/10.5937/GeoPan1203094B

Brankov J, Jojić Glavonjić T, Milanović Pešić A, et al. (2019) Residents' Perceptions of Tourism Impact on Community in National Parks in Serbia. European Countryside 11: 124-142. https://doi.org/10.2478/euco-2019-0008

Childs G, Craig S, Beall CM, Basnyat B (2014) Depopulating the Himalayan highlands: education and outmigration from ethnically Tibetan communities of Nepal. Mountain Research and Development 34: 85-95.

https://doi.org/10.1659/MRD-JOURNAL-D-14-00021.1

Collantes F, Pinilla V (2004) Extreme depopulation in the Spanish rural mountain areas: a case study of Aragon in the nineteenth and twentieth centuries. Rural History 15: 149-166. https://doi.org/10.1017/So956793304001219

Coxon C (2011) Agriculture and Karst. In: van Beynen PE (ed.), Karst Management. Springer Netherlands, Dordrecht. pp 103138

Devedžić M (2007) Subject of Research on Effects of Tourism on Population Development. Stanovništvo 45: 63-79

Duval M (2006) Tourism and Preservation Policies in Karst Areas: Comparision Betwen the Škocjan Caves (Slovenia) and the Ardèche Gorge (France). Acta Carsologica 35/2-3: 23-35. https://doi.org/10.3986/ac.v35i2-3.225

Farsani NT, Coelho C, Costa C (2011) Geotourism and geoparks as novel strategies for socio-economic development in rural areas. International Journal of Tourism Research 13: 68-81. https://doi.org/10.1002/jtr.80o

Frost W, Hall CM (2015) Tourism and national parks: international perspectives on development, histories and change. Routledge, New York

Gams I (1993) Origin of the term "karst," and the transformation of the classical karst (kras). Environmental Geology 21: 110-114. https://doi.org/10.1007/BFo0775293

Geološki Institut Srbije (2009) Osnovne geološke karte Srbije 1:100.00o. Available at http://geoliss.mre.gov.rs/OGK/ RasterSrbija/, accessed on 2019-07-19.

Grau HR, Aide TM (2007) Are rural-urban migration and sustainable development compatible in mountain systems? Mountain Research and Development 27:119-124. https://doi.org/10.1659/mrd.0906

Gretter A, Machold I, Membretti A, Dax T (2017) Pathways of Immigration in the Alps and Carpathians: Social Innovation and the Creation of a Welcoming Culture. Mountain Research and Development 37: 396-405. https://doi.org/10.1659/MRD-JOURNAL-D-17-00031.1

Gutiérrez F, Parise M, De Waele J, Jourde H (2014) A review on provided you give appropriate credit to the original author(s) and the source, provide a link to the Creative Commons license, and indicate if changes were made. natural and human-induced geohazards and impacts in karst. Earth-Science Reviews 138: 61-88.

https://doi.org/10.1016/j.earscirev.2014.08.002

Head-König AL (2011) Migration in the Swiss Alps and Swiss Jura from the Middle Ages to the mid-2oth century: a brief review. Journal of Alpine Research | Revue de géographie alpine. https://doi.org/10.400o/rga.1359

Henriques MH, Brilha J (2017) UNESCO Global Geoparks: a strategy towards global understanding and sustainability. Episodes 40: 349-354.

https://doi.org/10.18814/epiiugs/2017/v40i4/017036

Kizos T, Vasdeki M, Chatzikiriakou C, Dimitriou D (2011) 'For my children': Different functions of the agricultural landscape and attitudes of farmers on different areas of Greece towards small scale landscape change. Geografisk Tidsskrift-Danish Journal of Geography 111: 117-130.

https://doi.org/10.1080/00167223.2011.10669528

Kohler T, Elizbarashvili N, Meladze G, et al. (2017) The demogeographic crisis in Racha, Georgia: Depopulation in the central Caucasus mountains. Mountain Research and Development 37: 415-425.

https://doi.org/10.1659/MRD-JOURNAL-D-17-00064.1

Latocha A (2012) Changes in the rural landscape of the Polish Sudety Mountains in the post-war period. Geographia Polonica 85: 13-21. https://doi.org/10.7163/GPol.2012.4.21

Latocha A (2013) The depopulated villages in the Sudetes. And what next? Przegląd Geograficzny 85: 373-396. https://doi.org/10.7163/PrzG.2013.3.3

Latocha A, Szymanowski M, Jeziorska J, et al. (2016) Effects of land abandonment and climate change on soil erosion-An example from depopulated agricultural lands in the Sudetes Mts., SW Poland. Catena 145: 128-141. https://doi.org/10.1016/j.catena.2016.05.027

Latocha A, Szymanowski M, Wieczorek M (2018) Wyludnianie powiatu kłodzkiego - przestrzenne zróżnicowanie i uwarunkowania(Depopulation of the Kłodzko region - spatial differences and conditioning). Przegląd Geograficzny 90: 241266. https://doi.org/10.7163/PrzG.2018.2.3

Li Y, Liu Y, Long H, Wang J (2013) Local responses to macro development policies and their effects on rural system in China's mountainous regions: the case of Shuanghe Village in Sichuan Province. Journal of Mountain Science 10: 588-608. https://doi.org/10.1007/s11629-013-2544-5

Löffler R, Beismann M, Walder J, Steinicke E (2014) New Highlanders in traditional out-migration areas in the Alps. The example of the Friulian Alps. Journal of Alpine Research| Revue de Géographie Alpine 1-17.

https://doi.org/10.400o/rga.2546

MacDonald D, Crabtree JR, Wiesinger G, et al. (2000) Agricultural abandonment in mountain areas of Europe: Environmental consequences and policy response. Journal of Environmental Management 59: 47-69.

https://doi.org/10.1006/jema.1999.0335

Mao X, Meng J, Wang Q (2014) Tourism and land transformation: A case study of the Li River Basin, Guilin, China. Journal of Mountain Science 11: 1606-1619. https://doi.org/10.1007/s11629-013-2871-6

McNeill JR (2003) The Mountains of the Mediterranean World. Cambridge University Press. 
Mercier G (2009) Vidal de la Blache, P. In: Kitchin R, Thrift N (eds.), International Encyclopedia of Human Geography. Elsevier, Oxford. pp 147-150.

Milošević MV, Milivojević M, Ćalić J (2010) Spontaneously abandoned settlements in Serbia, Part 1. Journal of the Geographical Institute “Jovan Cvijić" SASA 6o/2: 39-57. https://doi.org/10.2298/IJGI1002039M

Milošević MV, Milivojević M, Ćalić J (2011) Spontaneously abandoned settlements in Serbia, Part 2. Journal of the Geographical Institute “Jovan Cvijić" SASA 61/2: 25-35. https://doi.org/10.2298/IJGI1102025M

Mose I (ed.) (2007) Protected Areas and Regional Development in Europe: Towards a New Model for the 21st Century. Ashgate Publishing, Ltd.

Okahashi H (1996) Development of mountain village studies in postwar Japan. Geographical review of Japan, Series B 69: 60-69.

Parise M, De Waele J, Gutierrez F (2009) Current perspectives on the environmental impacts and hazards in karst. Environmental Geology 58: 235-237. https://doi.org/10.1007/s00254-008-1608-2

Patterson LA, Doyle MW (2011) Hypsographic Demography Across Scale. The Professional Geographer 63: 514-530. https://doi.org/10.1080/00330124.2011.578534

Pawson E, Egli HR (2001) History and (Re)discovery of the European and New Zealand Alps until 1900. Mountain Research and Development 21: 350-358. https://doi.org/10.1659/02764741(2001)O21[0350:HARDOT]2.o.CO;2

Pejnović D, Husanović-Pejnović D (2008) Causes and consequences of demographic development in the territory of Velebit Nature Park, 1857-2001. Periodicum biologorum 110: 195-204.

Rabus B, Eineder M, Roth A, Bamler R (2003) The shuttle radar topography mission -a new class of digital elevation models acquired by spaceborne radar. ISPRS journal of photogrammetry and remote sensing 57: 241-262. https://doi.org/10.1016/So924-2716(02)00124-7

Ristić Vakanjac V, Stevanović Z, Maran Stevanović A, et al. (2015) An example of karst catchment delineation for prioritizing the protection of an intact natural area. Environmental Earth Sciences 74: 7643-7653. https://doi.org/10.1007/978-3-642-17435-3_44

Romano B (1995) National Parks Policy and Mountain Depopulation: A Case Study in the Abruzzo Region of the Central Apennines, Italy. Mountain Research and Development 15: 121-132. https://doi.org/10.2307/3673876

Sitzia T, Semenzato P, Trentanovi G (2010) Natural reforestation is changing spatial patterns of rural mountain and hill landscapes: A global overview. Forest Ecology and Management 259: 1354-1362.

https://doi.org/10.1016/j.foreco.2010.01.048

Small C, Cohen J (2004) Continental physiography, climate, and the global distribution of human population. Current Anthropology 45: 269-277. https://doi.org/10.1086/382255

Telbisz T, Bottlik Z, Mari L, Kőszegi M (2014) The impact of topography on social factors, a case study of Montenegro. Journal of Mountain Science 11: 131-141.

https://doi.org/10.1007/s11629-012-2623-z

Telbisz T, Bottlik Z, Mari L, Petrvalská A (2015) Exploring relationships between Karst terrains and social features by the example of Gömör-Torna Karst (Hungary-Slovakia). Acta Carsologica 44/1: 121-137. https://doi.org/10.3986/ac.v44i1.1739

Telbisz T, Imecs Z, Mari L, Bottlik Z (2016) Changing humanenvironment interactions in medium mountains: the Apuseni Mts (Romania) as a case study. Journal of Mountain Science 13: 1675-1687. https://doi.org/10.1007/S11629-015-3653-0

Telbisz T, Stergiou CL, Mindszenty A, Chatzipetros A (2019) Geological and Geomorphological Characteristics of Vikos Gorge and Tymphi Mountain (Northern Pindos National Park, Greece) and Karst-Related Social Processes of the Region. Acta Carsologica 48/1: 29-42. https://doi.org/10.3986/ac.v48i1.6806

Toniolo AR (1937) Studies of Depopulation in the Mountains of Italy. Geographical Review 27: 473-477. https://doi.org/10.2307/210332

Vaishar A, Zapletalová J, Dvořák P, et al. (2018) Recent population development in sensitive karst areas: case studies of the Moravian Karst (Czech Republic) and the Devetashko Plateau (Republic of Bulgaria). Problems of Geography 3-4: 88-109.

Viazzo PP, Zanini RC (2014) "Taking advantage of emptiness?" Anthropological perspectives on mountain repopulation and spaces of cultural creativity in the Alpine area. Journal of Alpine Research, Revue de Géographie Alpine. https://doi.org/10.400o/rga.2478

Vogiatzakis I (2012) Mediterranean Mountain Environments. John Wiley \& Sons. https://doi.org/10.1002/9781119941156

Wang C, Zhang Y, Yang Y, et al. (2019) What is driving the abandonment of villages in the mountains of Southeast China? Land Degradation \& Development 30: 1183-1192. https://doi.org/10.1002/ldr.3303

Zhang C, Day M, Li W (2003) Land use and land cover change in the Lunan Stone Forest, China. Acta Carsologica 32/2: 161174. https://doi.org/10.3986/ac.v32i2.345 